\title{
Determining the effectiveness of Candida guilliermondii in the biological control of Rhizopus stolonifer in postharvest tomatoes
}

\author{
Crispin Celis Zambrano ${ }^{1}$, Gerardo Moreno Duran ${ }^{2}$, Luis Gonzalo Sequeda-Castañeda ${ }^{1}$, \\ Andrea García Caicedo 1 , Diana Marcela Albarracín², Luz Claudia Barreto Charry ${ }^{2}$
}

\begin{abstract}
Post-harvest losses in tomato crops can be accredited to a number of causes, which include biological causes that produce physiological deterioration; infection caused by diseases and pests that cause rotting. In this study, we assayed, in vitro and in vivo, the yeast Candida guilliermondii to determine its effectiveness as a biocontrol to reduce the rotting produced by Rhizopus stolonifer on tomatoes (Lycopersicon esculentum). The antagonistic effect was tested using a yeast biomass suspension; gas chromatography and a mass selective detector were used to identify its metabolites. According to the in vitro test, the only phase with an antagonistic response against Rhiropus stolonifer was the unfiltered water phase. In the in vivo tests, the biomass of Candida guilliermondii presented the highest percentage of protection of the tomato $(87 \%)$ compared with the unfiltered aqueous phase and the unconcentrated organic phase, which reached only 77 and $80 \%$ respectively. These results are essential to avoid economic losses caused by fungi and to increase the shelf life of tomatoes improving the distribution of the product and preventing postharvest losses in this time of food crises, especially in developing countries.
\end{abstract}

Keywords: Biological control; Candida guilliermondii; Rhizopus stolonifer, tomato; Lycopersicon esculentum.

Edited by Alberto Acosta

1 Departamento de Química, Facultad de Ciencias, Pontificia Universidad Javeriana, Bogotá D.C. Colombia.

2 Departamento de Microbiología, Facultad de Ciencias, Pontificia Universidad Javeriana, Bogotá D.C. Colombia.

Received: 16-10-2013 Accepted: 21-11-2013

Published on line: 21-12-2013

Citation: Celis C, Moreno G, Sequeda-Castañeda L, García A, Albarracín D, Barreto L (2014) Determining the effectiveness of biological control of Rhizopus stolonifer in tomatoes postharvest decay using Candida guilliermondii. Universitas Scientiarum 19(1): 51-62 doi: 10.11144/Javeriana.SC19-1. debc

Funding: Vicerrectoría Academica at Pontificia Universidad Javeriana-Bogotá

Electronic supplementary material: N/A

SICI:

2027-1352(201401/03)19:1<051:DTEOCGITBCORSIPT>2.0.TS;2-O

\section{Introduction}

The tomato (Lycopersicon esculentum) is one of the most popular fruits in the world; it is consumed in large quantities. Because of its huge production potential, it can be cultivated in a variety of climates and soils (Nuez 2001). Globally, the annual production of tomatoes is approximately 160 million tons, about $21 \%$ is lost due to biological diseases; this represents a large economic loss for producers and marketers (FAO 2012). This fruit has a short shelf life. Its production can be affected by inadequate farming and harvesting techniques as well as various environmental factors such as temperature and humidity (FAO 1997), which can originate physiopathies such as blossom end rot, sunburn, fissured fruit and nutrient deficiencies (Jones et al. 1991, Heuvelink 2005). Fungi 
can also affect tomatoes; these fungi include Fusarium oxysporium, Fusarium moniliform, Aspergillus niger and Rhizopus stolonifer (Onuegbu 2002). The latter, Rhizopus stolonifer, causes soft rot on tomatoes; its rapid growth and easy transmission through handling and damaging of the fruits can generate significant economic losses during the postharvest phase (Badawy \& Rabea 2009). The first option for controlling tomato postharvest diseases is the use of synthetic fungicides. The use of these fungicides has been challenged worldwide due to the severe environmental problems they cause and rapid resistance developed by the bacterium, which renders their use ineffective (Spadaro \& Gullino 2004, 2010, Domínguez et al. 2012). Biological control of phytopathogens during postharvest storage is a promising alternative; it is innocuous to the environment, favored from a public health perspective and positive economically (Cook et al. 1992, Morin et al. 2009). Because of their antagonistic capacity against other microorganisms, yeasts have been recognized as potential biocontrol agent (Cook et al. 1999). Some species of yeast such as Candida sake and Candida pulcherrima can colonize tomato plant stem-wounds and control gray mold (Cook et al. 1997, Dik et al. 1999). Other yeast such as Rhodotorula glutinis and Cryptococcus albidus can penetrate tomato leaves to control Botrytis cinerea (Elad 2000). Scanning electron microscopy revealed that heat treatment at $38{ }^{\circ} \mathrm{C}$ for $24 \mathrm{~h}$ inhibited hyphae growth and spore germination of R. stolonifer on fruit wounds while P. guilliermondii multiplied rapidly; its cells had a strong capability of adhesion to the hyphae of $R$. stolonifer. However, the heat treatment seriously affected $P$. guilliermondii, therefore, P. guilliermondii should be applied after heat treatment (Wisniewski et al. 1991, Zhao et al. 2010). Cryptococcus laurentii has been reported to be a depressor of postharvest decay of cherry tomatoes caused by B. cinerea and Pythium aphanidermatum Edson (Xi \& Tian 2005). Yeast has also been reported as a biocontrol for blue mold on citrus fruits, as well as the mode of action of an isolate of Pichia guilliermondii; the activity against the pathogen declined when the number of yeast cells inoculated in the wound was reduced. Cell numbers increased by up to 60 -fold within $24 \mathrm{~h}$, despite it demonstrating good abilities to colonize the wound site and grow rapidly, (Arras et al. 1998). The examination of tomato peel colonization by the endophyte yeast, Candida guilliermondii, revealed that it is an endophytic yeast capable of entering through the healthy cuticle of ripe tomatoes and colonizing apoplastic spaces without causing damage to plant tissues. The dynamics of colonization and the speed of yeast migration into the fruit were established during the first 70 hours (Infante-Luna et al. 2012). Candida guillermondii is an opportunistic microorganism, usually harmless to a healthy host. It has been isolated from many human infections, typically of cutaneous origin; it has been also isolated from healthy skin and found in sea water, animal feces, fig wasps, buttermilk, leather, fish, beer, pickle brine, cured meats, olives and tomatoes; however, the consumption of these foods is not likely to cause these infections (Palumbo \& Harris 2011). The U.S Food and Drug Administration classified a Candida guillermondii culture collection (ATCC No. 20474) as nonpathogenic and nontoxicogenic organism suggesting that $C$. guillermondii is microbiologically safe (FDA 2013).

The examination of how yeasts work and of their real potential postharvest protection of tomatoes is vital. Fittingly, in this study we evaluated the antagonistic effects of Candida guilliermondii and its metabolites, inoculated separately or in combination into tomatoes to control postharvest decay caused by Rhizopus stolonifer using in vivo and in vitro assays.

\section{Materials and methods}

We firstly isolated Candida guilliermondii from a heterograft tomato crop (HGTC) in Sogamoso (Boyacá-Colombia) and subsequently classified it by API 20 as Candida spp. We then characterized it as Candida guilliermondii by molecular methods used by Borrero (2011) and stored in it in the microorganism bank of the Pontificia Universidad Javeriana (PUJ). We transferred $3 \mathrm{~mL}$ of preserved strain to $20 \mathrm{~mL}$ of Sabouraud's broth (Merck Millipore, Darmstadt, Germany) and incubated it at $30{ }^{\circ} \mathrm{C}$ for 5 days. Following the standardized protocols of the microbiological chemistry laboratory of the PUJ, we plated the new cells obtained on Sabouraud agar (Merck Millipore, Darmstadt, Germany) to confirm their purity using macroscopic and microscopic observations. A pure pre-inoculum of $200 \mathrm{~mL}$ was transferred to a batch reactor $(5 \mathrm{~L})$ using two liters 
of Sabouraud's broth. The fermentation was carried out for 36 hours according to the description made by Borrero (2011). We filtered a half-liter of fermented medium using a $0.45 \mu \mathrm{m}$ membrane (Merck Millipore, Darmstadt, Germany) to obtain the filtered aqueous phase and the Candida guilliermondii biomass.

Metabolite extraction and identification: We isolated the metabolites produced by Candida guilliermondii from the filtered aqueous phase using a continuous liquid-liquid (L-L) extractor (Sigma-Aldrich Co. St. Louis, USA) for 72 hour using dichloromethane as a solvent (Merck Millipore, Darmstadt, Germany). The number of volatile metabolites was determined using a gas chromatograph (VARIAN 3350, Palo Alto, California, USA) and a Varian 8200CX autosampler, with a 48-vial capacity, with a $10 \mu \mathrm{L}$ syringe (SGE analytical Science, Melbourne, Australia) injecting 1 $\mu \mathrm{L}$ in a splitless mode injector (Varian 1075 model$250{ }^{\circ} \mathrm{C}$ ). The oven was equipped with a $30 \mathrm{~m} \times 0.53$ mm x $1.0 \mu \mathrm{m}$ MET-WAT capillary column (SupelcoSigma-Aldrich Co. St. Louis, USA), temperature programmed at $35^{\circ} \mathrm{C}(1 \mathrm{~min}), 120^{\circ} \mathrm{C}$ a $7{ }^{\circ} \mathrm{C} / \mathrm{min}(3$ min), $190{ }^{\circ} \mathrm{C}$ a $10{ }^{\circ} \mathrm{C} / \mathrm{min}(2 \mathrm{~min})$, and a $220{ }^{\circ} \mathrm{C}$ a 10 ${ }^{\circ} \mathrm{C} / \mathrm{min}(1 \mathrm{~min}$ ), and a flame ionization detector (FID$\left.280{ }^{\circ} \mathrm{C}\right)$ using helium as carrier gas $(2.8 \mathrm{~mL} / \mathrm{min})$. We identified the metabolites present in the organic phase after L-L extraction using a gas chromatograph (GC) Agilent 6890 Series Plus (Agilent Technologies, Palo Alto, California, USA) equipped with a mass selective detector (MSD, Agilent 5973-Network) using a SPB-1 $60 \mathrm{~m}$ x $0.25 \mathrm{~mm}$ x $0.25 \mu \mathrm{m}$ capillary column (Supelco-Sigma-Aldrich Co. St. Louis, USA), carrier gas helium and temperature programmed at $45{ }^{\circ} \mathrm{C}$ (1 min), $250{ }^{\circ} \mathrm{C}$ a $5{ }^{\circ} \mathrm{C} / \mathrm{min}(30 \mathrm{~min})$. An analyzer at $34.6 \mathrm{~mA}$, ion focus $88.9 \mathrm{v}$, electron energy at 69 $\mathrm{eV}$, scan speed at $2.8 \mathrm{scan} / \mathrm{seg}$, filament off $2 \mathrm{~min}$ and mass ranges $40-400$ u.m.a.s. We identified the metabolites by comparing the fragment ions obtained for the sample with those reported in the Wiley and NIST database. Library searches were performed using ChemStation B.02.02. Software for Wiley library and Mass Spectral Search Program 1.1.a for NIST libraries. In order to establish the presence of metabolite in the aqueous phase after L-L extraction, we performed a column chromatography using silica gel (70 - 230 mesh Supelco-Sigma - Aldrich Co. St. Louis, USA) as stationary phase and methanol (Merck
Millipore, Darmstadt, Germany) as eluent, which was concentrated and analyzed by GC-MSD.

Pathogenicity assay: The pathogenicity test was conducted using a Rhiropus stolonifer strain taken from the microorganism bank at the PUJ. We suspended the mycelium in $9 \mathrm{~mL}$ of Tween 80 at $0.1 \%$, stirred for 1 minute and filtered to remove the mycelial mass. The concentration was adjusted to $10^{3}, 10^{4}$ and $10^{5}$ sporangiospores/mL using a Neubauer chamber. To avoid the occurrence of pesticides, the tomatoes used in all the tests came from an organic farm in Choachí (Colombia). We first washed and disinfected the tomatoes then made two equatorial wounds in each fruit using a $3 \mathrm{~mm}^{2}$ sterile perforating punch. The wounds were inoculated with $25 \mu \mathrm{L}$ of each pathogen concentration tested. The samples were left at room temperature in sterile aluminum containers each one contained three tomatoes and was covered with sterile plastic wrap. We performed the treatments ten times each for 6 days measuring the lesion diameter daily, the mycelial growth and the fungus sporulation. Tomatoes inoculated with Tween 80 at $0.1 \%$ were used as control. We validated the results employing a variance analysis (ANOVA) and Tukey test $(\alpha<0.05)$ using XLSTAT software.

Selecting phases with antagonistic effect: We performed the in vitro test using the Wells technique to select the phases obtained from the fermentation process that inhibit pathogen growth. The technique consisted in plating the pathogen in each Petri dish; the wells were then inoculated with Sabouraud agar containing each phase in study (Table 1). We incubated the Petri dishes at $25{ }^{\circ} \mathrm{C}$ and measured the zones of inhibition after 24 hours. Triplicate sets of plates were prepared on each occasion, and every experiment repeated three times.

Protection Assay: The protection assay was performed with tomatoes from an organic crop and processed according to described in pathogenicity assay section. The yeast $\left(10^{8}\right.$ cells $\left./ \mathrm{mL}\right)$ was suspended in Tween $80(0.1 \%)$ and $25 \mu \mathrm{L}$ were inoculated in each tomato wound. Other tomatoes were inoculated with unfiltered aqueous phase and unconcentrate organic phase due to the previous results obtained which suggest antagonistic effects (Table 1). All the inoculated tomatoes were processed as described 
Table 1. Phases used in the in vitro (A-F) and in vivo (G-K) assay to determine the antagonistic effect and potential biocontrol of Rhizopus stolonifer on tomatoes. The antagonist and the pathogen were inoculated at different times.

\begin{tabular}{|c|c|c|c|c|c|c|c|}
\hline \multirow{2}{*}{$\begin{array}{l}\text { In vitro } \\
\text { assay }\end{array}$} & \multirow[b]{2}{*}{ Process } & \multirow[b]{2}{*}{ Characteristic } & \multirow{2}{*}{$\begin{array}{l}\text { In vivo } \\
\text { assay }\end{array}$} & \multirow[b]{2}{*}{ Process } & \multirow[b]{2}{*}{ Characteristic } & \multicolumn{2}{|c|}{ Inoculationtime (hours) } \\
\hline & & & & & & Antagonist & Rhizopussp. \\
\hline A & Fermentation & Unfiltered aqueous phase & G & Fermentation & Unfiltered aqueous phase & 0 & 24 \\
\hline B & Filtration & Filtered aqueous phase & $\mathbf{H}$ & Filtration & Candida guilliermondii biomass & 0 & 24 \\
\hline $\mathrm{C}$ & Extraction & Unconcentrated organic phase & I & Extraction & Unconcentrated organic phase & 0 & 24 \\
\hline D & Extraction & Recovered aqueous phase & $\mathbf{J}$ & Absolute control & Twen $80(0.1 \%)$ & 0 & 24 \\
\hline $\mathrm{E}$ & Concentration & Concentrated organic phase & \multirow[t]{2}{*}{$\mathbf{K}$} & Pathogen control & \multirow{2}{*}{ Rhizopus sp. } & \multirow[t]{2}{*}{ - } & \multirow[t]{2}{*}{24} \\
\hline $\mathrm{F}$ & Control & Sterile distilled water & & $10^{5}$ sporangiospores $/ \mathrm{mL}$ & & & \\
\hline
\end{tabular}

above. After 24 hours, $25 \mu \mathrm{L}$ of Rhizopus stolonifer suspension adjusted to $10^{5}$ sporangiospores $/ \mathrm{mL}$ were applied in every tomato wound. Assessments were performed daily, and disease symptoms in tomato fruits inoculated with Rbizopus stolonifer were evaluated by measuring the diameters of lesions every 24 hours for 6 days. The results were analyzed by comparing the lesion diameters of each treatment over the controls obtaining the percentage of inhibition for each treatment. Every treatment and control calculation was based on results obtained from 30 replicates.

\section{Results}

Macroscopic and microscopic description: The Gram stain displayed oval cells of considerable diameter in the budding stage and was Gram-positive (Figure 1a). Candida guilliermondii colonies had a white color, creamy texture and elevated, regular border. After verifying their characteristics and purity, the yeast was used in the fermentation processes.

Metabolite identification: We analyzed the unconcentrate organic phase using GC-FID; it showed 12 volatile metabolites, which we identified using GC-MSD analysis. The higher relative proportions corresponded to ethyl acetate $(79.1 \%)$, isopentyl alcohol (5.7 \%) and phenyl ethyl alcohol (4.5\%), Table 2 summarizes the results. The aqueous phase recovered after L-L extraction exhibited a minimal amount of volatile metabolites; this was correlated with the low biological activity of this phase (Figure 1b).
Selecting phases with antagonistic effect to Rhizopus stolonifer: The results of in vitro tests revealed that the unfiltered water phase inhibited the growth of Rhizopus stolonifer. The massive growth of the fungus throughout the Petri dish, revealed the lack of any inhibitory effect in the other assay phases. The unfiltered water phase is derived from the Candida guilliermondii fermentation at 36 hours. This phase contains the fermentative medium, biomass yeast and the metabolites produced. Because the other phases did not show any activity, it could be inferred that biomass yeast has an inhibitory effect against the pathogen.

Pathogenicity assay: After 48 hours, tomatoes inoculated with Rhizopus stolonifer showed symptoms of deterioration such as tissue softening around the wound, skin breakdown with continuous liquid exudate, abundant external mycelia growth turning from white to gray over the time until covered the artificial wound and finally all the fruit as described by Singleton et al. (1993). The fungal pathogen presented mycelial growth from the third day and abundant sporulation on the sixth day. The assay with concentration of $10^{5}$ sporangiospores $/ \mathrm{mL}$ exhibited a lesion diameter of $57 \mathrm{~mm}$ on the sixth day whereas concentrations of $10^{3}$ and $10^{4}$ sporangiospores $/ \mathrm{mL}$, displayed 14 and 40 $\mathrm{mm}$ diameters respectively (Figure 2 ). According to the statistical analysis, $100 \%$ of pathogen incidence in tomatoes corresponded to $10^{5}$ sporangiospores/ $\mathrm{mL}$. Resultantly, this concentration was selected to perform the protection assay. 
Table 2. Metabolites identified by GC/MSD in the unconcentrated organic phase. Metabolite identification was performed by comparing fragment ions obtained for the sample with those reported in the Wiley and NIST database.

Metabolite $\begin{gathered}\text { Retention time } \\ (\mathrm{min})\end{gathered} \quad$ Compound $\quad \begin{gathered}\text { Relative abundance } \\ (\%)\end{gathered}$

\begin{tabular}{|c|c|c|c|}
\hline 1 & 5.39 & Ethyl acetate & 79.1 \\
\hline 2 & 5.5 & Isobutyl alcohol & 2.0 \\
\hline 3 & 7.21 & Isopentyl alcohol & 5.7 \\
\hline 4 & 7.3 & 2-Methyl-butanol & 1.9 \\
\hline 5 & 7.72 & Isobutyric acid & 0.6 \\
\hline 6 & 9.57 & Isovaleric acid & 0.8 \\
\hline 7 & 10.16 & 2-Methyl butyric acid & 0.5 \\
\hline 8 & 17.59 & 2-phenyl ethanol & 4.5 \\
\hline 9 & 33.38 & $\begin{array}{l}\text { 2,5,5-Trimethyl-1,3- } \\
\text { cyclohexanedione }\end{array}$ & 1.3 \\
\hline 10 & 35.03 & 2,6-Dimethoxyphenol & 1.4 \\
\hline 11 & 36.08 & 2-phenyl ethyl acetate & 0.4 \\
\hline 12 & 37.44 & 3-Hydroxy-2-butanone & 1.7 \\
\hline
\end{tabular}

Protection Assay: In the treatment where Candida guilliermondii and the pathogen were inoculated, we observed a significant reduction in both lesion development and pathogenic manifestation (Figure 3b). There was neither necrosis nor fruit tissue breakdown when the wound was treated with Candida guilliermondii, in contrast to the pathogen control, which had an increased lesion diameter from the third day until the fruit was completely invaded, akin to the results observed in the pathogenicity tests (Figure 3a). The percentage of tomato protection obtained was $87 \%$; this indicates that Candida guilliermondii has high biocontrol activity against Rhiropus stolonifer. After the sixth day, lesion diameter progressively increased in the tomato control group, whereas most of the tomatoes treated with the pathogen and yeast biomass did no show symptoms caused by the pathogen. The treatments treated with unfiltered water phase and the pathogen simultaneously presented a lesion diameter reduction in comparison to the pathogen control 
Fig. 1. a) Yeast characterization. Left side: Macroscopic characteristics of Candida guilliermondii colonies in Sabouraud agar. Right side: Microscopic characteristics of Candida guilliermondii obtained by Gram staining. b) Typical chromatograms for phases analyzed by GC-FID. Left side: Unconcentrate organic phase. Right side: Aqueous phase recovered after liquid-liquid extraction.

a

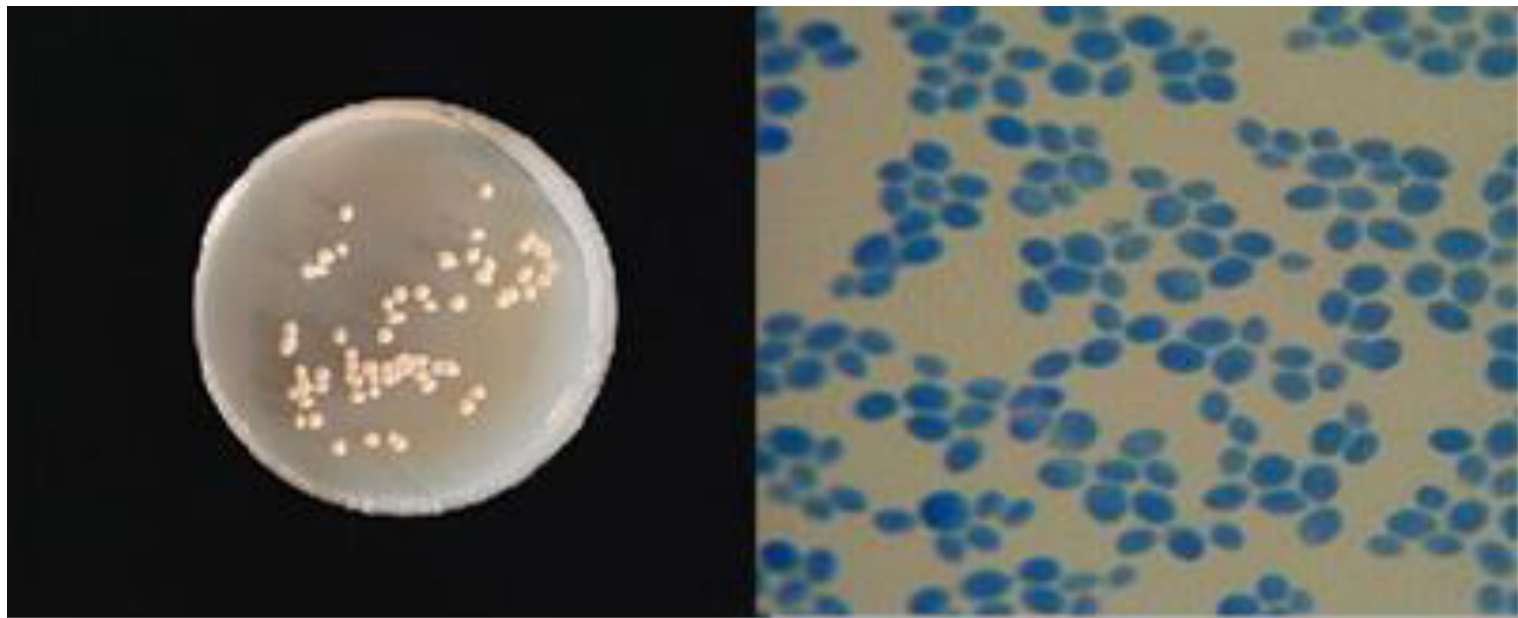

$\mathrm{b}$

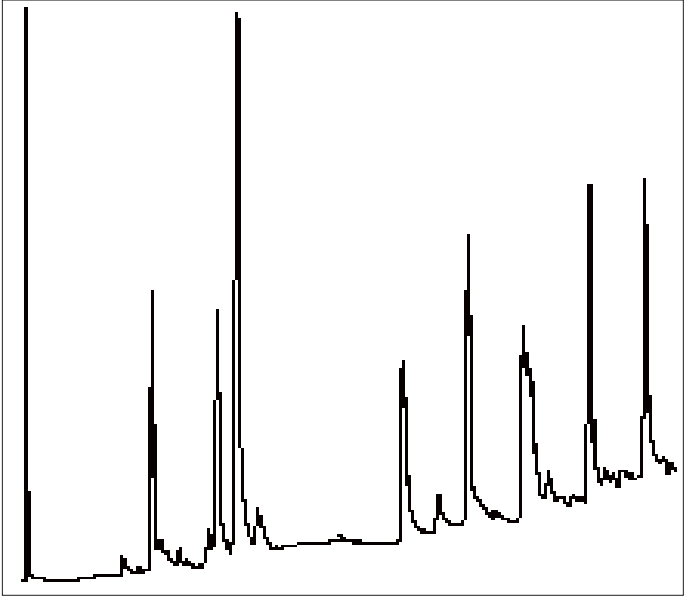

Unconcentrate organic phase

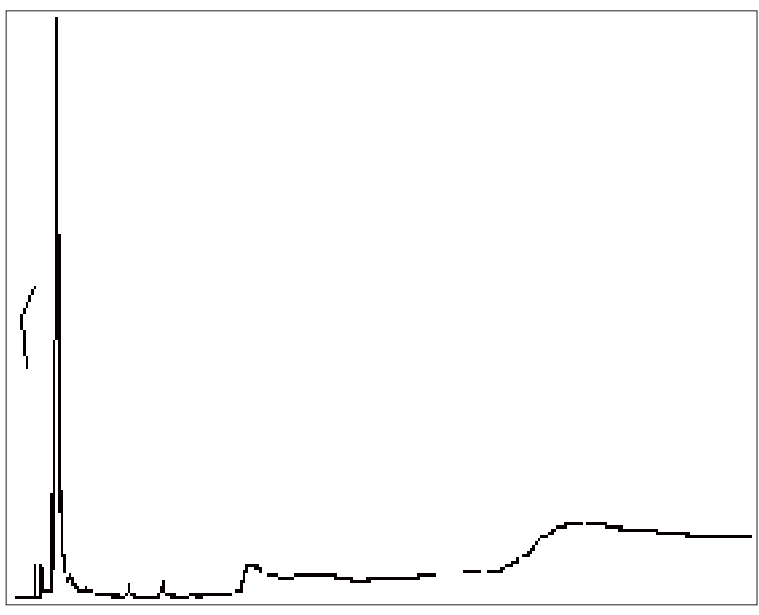

Aqueous phase recovered after L-L extraction
(Figure 3c); the percentage protection was $77 \%$ lower than the value obtained with Candida guilliermondii biomass. Treatments made with unconcentrate organic phase had $80 \%$ affectivity; this means that metabolites have a protective effect because of the adverse effect of the higher alcohols against some microorganism such as Rhiropus stolonifer. Some samples in this treatment revealed an abundant pathogen growth on the lesion areas and also characteristic symptoms of pathogenic occurrence (Figure 3d).

\section{Discussion}

We used the same pathogen concentrations $\left(10^{5}\right.$ sporangiospores $/ \mathrm{mL}$ ) as those used by Stevens et al. (1997). A $100 \%$ incidence was reported in this assay; the diameters of the lesions, however, were $12.5 \mathrm{~mm}$ and $26.1 \mathrm{~mm}$ in two varieties of tomato compared with those obtained in this study $(57 \mathrm{~mm})$. These differences may be due to susceptibility degree for every host variety or the virulence variability of different pathogenic strains. In the protection assay, 
Fig. 2. a. Statistical analysis of diameters lesions caused by Rhizopus stolonifer on tomatoes in different concentrations $\left(10^{3}\right.$ sporangiospore $/ \mathrm{mL}, 10^{4}$ sporangiospore $/ \mathrm{mL}, 10^{5}$ sporangiospore $\left./ \mathrm{mL}\right)$ after 6 days of inoculation. Each concentration had 30 replicates. Incidence percentage a. $(\bullet)$ mean, $(\boldsymbol{\Delta} \boldsymbol{\nabla})$ maximum and minimum values, $(\mathbf{I})$ confidence limit (95\%), (I)standard deviation, ( --- ) average of all the data. b. (•) median, (I) 25 and 75 percentiles, (-- ) average of all the data

a

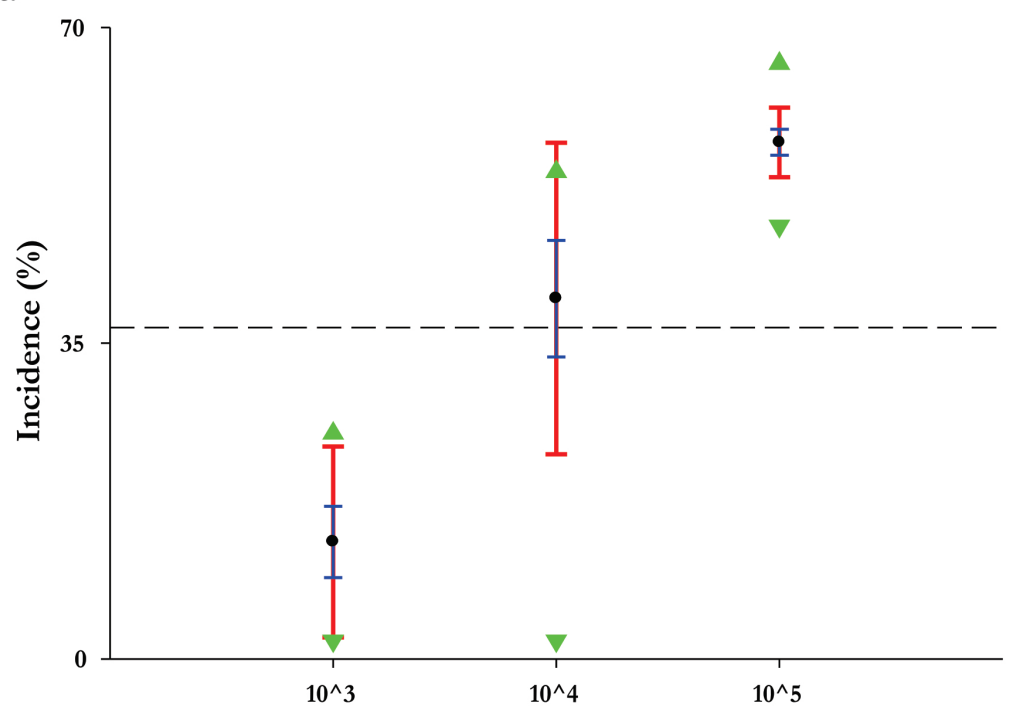

Concentration (esporangioespores $/ \mathrm{mL}$ )

b

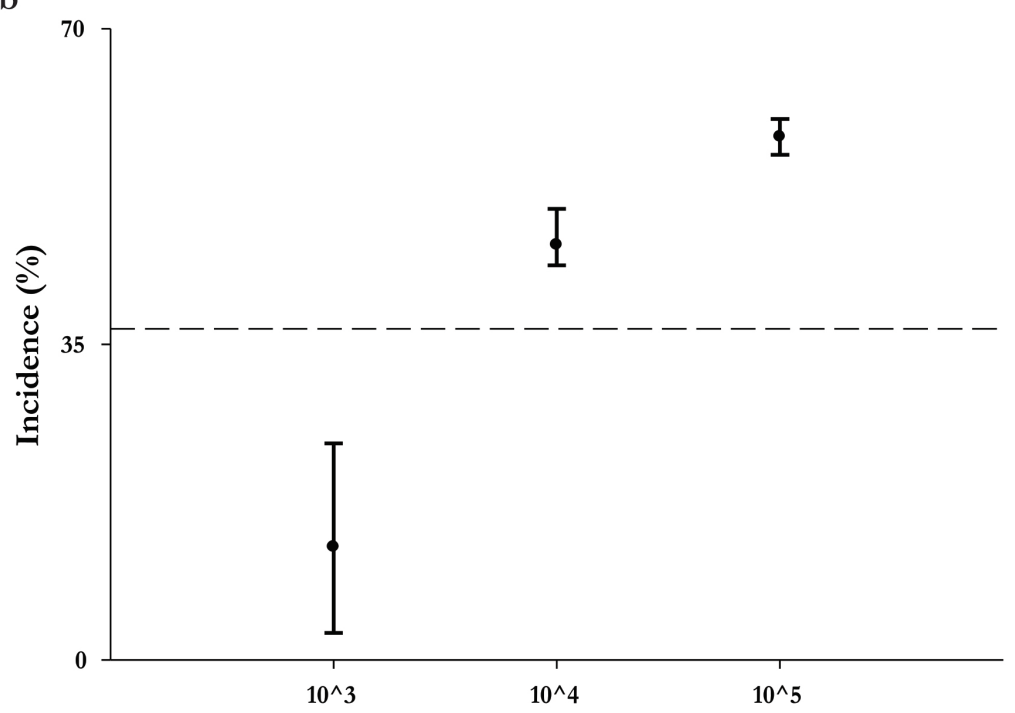

Concentration (esporangioespores $/ \mathrm{mL}$ )

some tomato samples showed similar symptoms as described previously, perhaps as a result of the low yeast concentration in the culture medium applied to the tomato or the high residual concentration of nutrients, or both, stimulated fungal growth. Roberts (1990) obtained similar results in their study on the biocontrol activity of Crytococcus laurentii against Botrytis cinerea in tomatoes.
Several yeast species such as Saccharomyces cerevisiae, Kloeckera apiculata, Candida utilis, Hansenula subpelliculosa, Pichia membranae faeciens, and Kluyveromyces marxianus have been reported to produce ethyl acetate (Plata et al. 2003) Candida utilis, Hansenula subpelliculosa, Pichia membranaefaeciens, Kluyveromyces marxianus (Rojas et al. 2001). The ester production ability of yeast differs among species and may depend on growing 
Fig. 3. Protection assays using tomatoes inoculated with a. Rbizopus stolonifer . b. Rhizopus stolonifer and Candida gillermondii. c. Rhizopus stolonifer and organic phase. d. Rhizopus stolonifer and water phase. e. Candida gillermondii biomass.
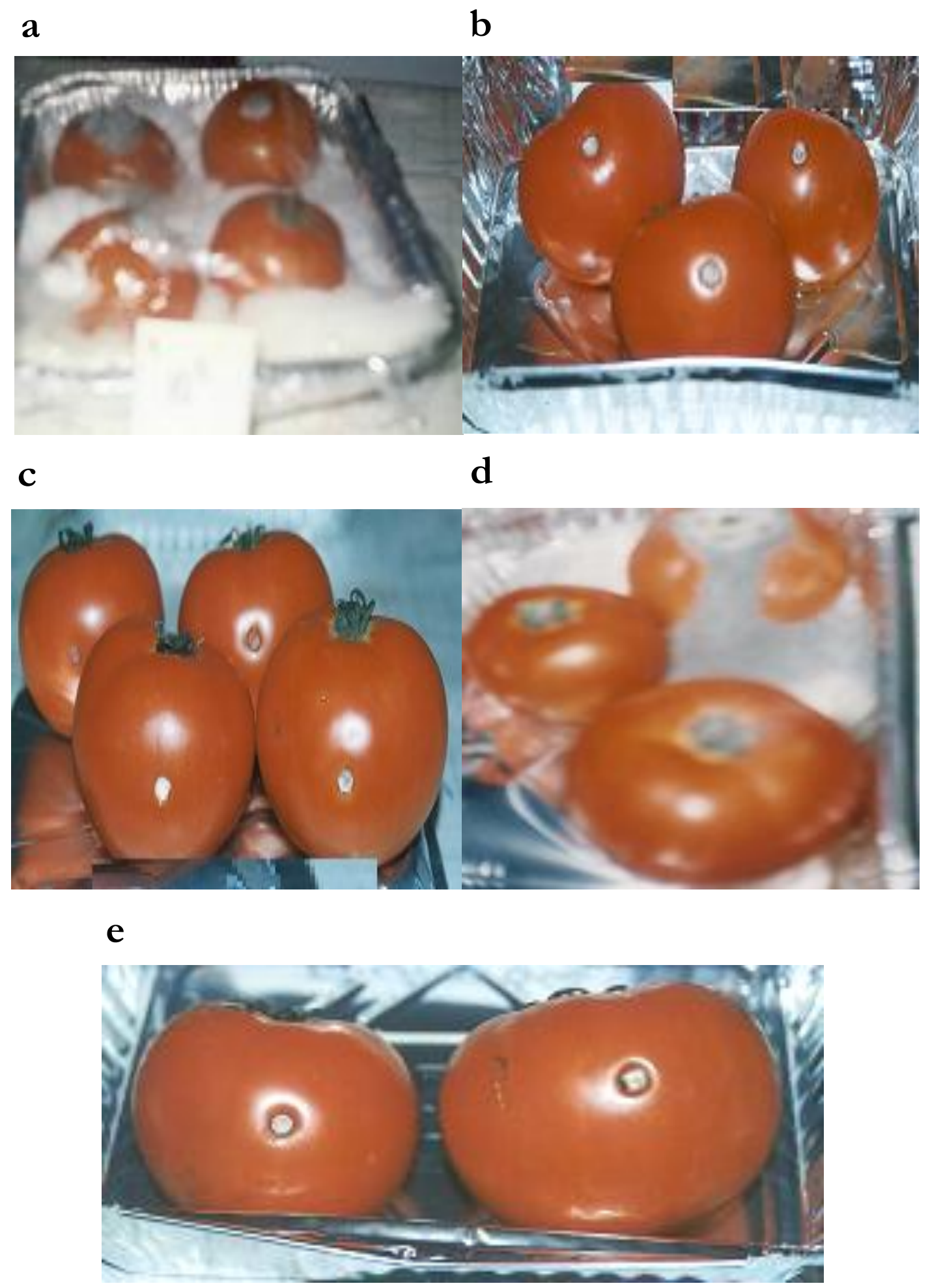

conditions. According to Peynaud (1956), Picchia and Hansenula produce large amounts of ethyl acetate, whereas Saccharomyces, Torulaspora and Kloeckera generate small amounts of this ester, this based on the production obtained with $C$. guillermondii. The first volatile metabolite in this production was ethyl acetate, 
which is responsible for the altered sensory properties of fermentation, for instance the unpleasant odor of the medium broth. Higher alcohols were obtained during the course of alcoholic fermentation by the deamination of amino acids to obtain nitrogen for its consumption or to produce other amino acids. Higher alcohols are organoleptically acceptable in low concentrations up to $300 \mathrm{ppm}$ when they begin to be unfavorable. Ando et al. (2012) established the presence of isopentyl alcohol, which completely inhibited the spore germination of 15 filamentous fungi including Rhizopus stolonifer at $20 \mathrm{ml} /$ dish, and inhibited the spore germination of all the tested filamentous fungi at $80 \mathrm{~mL} /$ dish. These results agree with our data in which the reported concentration of fungicidal activity was $5.1 \%$. The 2 -keto acids are intermediates for amino acid biosynthesis as they are the direct precursors of amino acids such as valine, isoleucine, and leucine, which allow the production of iso-acids as reported by GC/MSD analysis. They can be diverted to synthesize higher alcohols like isobutyl alcohol and 2-methyl-butanol, also reported in this study (Atsumi et al. 2008). It is also possible that the minor constituents determined here such as, isovaleric acid, isobutyric acid, 2-methyl-butyric acid, 3-hydroxy3-butanone, 2,6-dimethoxyphenol and 2-phenyl ethyl acetate may be involved in certain mechanism of antifungal synergism (Bajpai et al. 2008, Zabka \&
Pavela 2013) along with other active components in Candida guilliermondii fermentation.

Biomass of Candida guilliermondii reached the highest biocontrol effectiveness $(87 \%)$ compared to the unfiltered aqueous phase $(77 \%)$ and the unconcentrate organic phase ( $80 \%$; Figure 4). These results suggest that the best method for tomato postharvest protection against Rhizopus stolonifer is the use of yeast biomass. This result suggests that the best method for the postharvest tomato protection against Rhizopus stolonifer is the use of yeast biomass. Although these treatments did not differ significantly in terms of lesion diameter, the unfiltered aqueous phase and the unconcentrate organic phase achieved percentages lower than $85 \%$ (Figure 4) whereby these phases could not be used effectively to control the rot caused by Rhiropus stolonifer. The rapid colonization of Candida guilliermondii in the wound sites causes the absence of rot signs (Figure 3e) as it prevents the pathogen from settling in the damaged tomato as well as the germination of conidia. C. guilliermondii is an endophytic yeast that proficiently enters the healthy cuticle of mature tomatoes and settles in apoplastic spaces without spoiling the plant tissues. One of the advantages of $C$. guillermondii is its rapid migration to apoplastic spaces estimated at $0.55 \mu \mathrm{m}$ hour-1 (Infante-Luna et al. 2012). The secondary metabolites

Fig. 4. Effectiveness of Candida guilliermondii in the biological control of Rhizopus stolonifer in tomatoes, after 6 days of inoculation of three different phases. Each treatment had 30 replicates. Incidence percentage a. $(\bullet)$ mean, $(\boldsymbol{\Delta} \boldsymbol{\nabla})$ maximum and minimum values, (I) confidence limit (95\%), (I)standard deviation, ( -- ) average of all the data. b. (•) median, (I) 25 and 75 percentiles, (---) average of all the data.
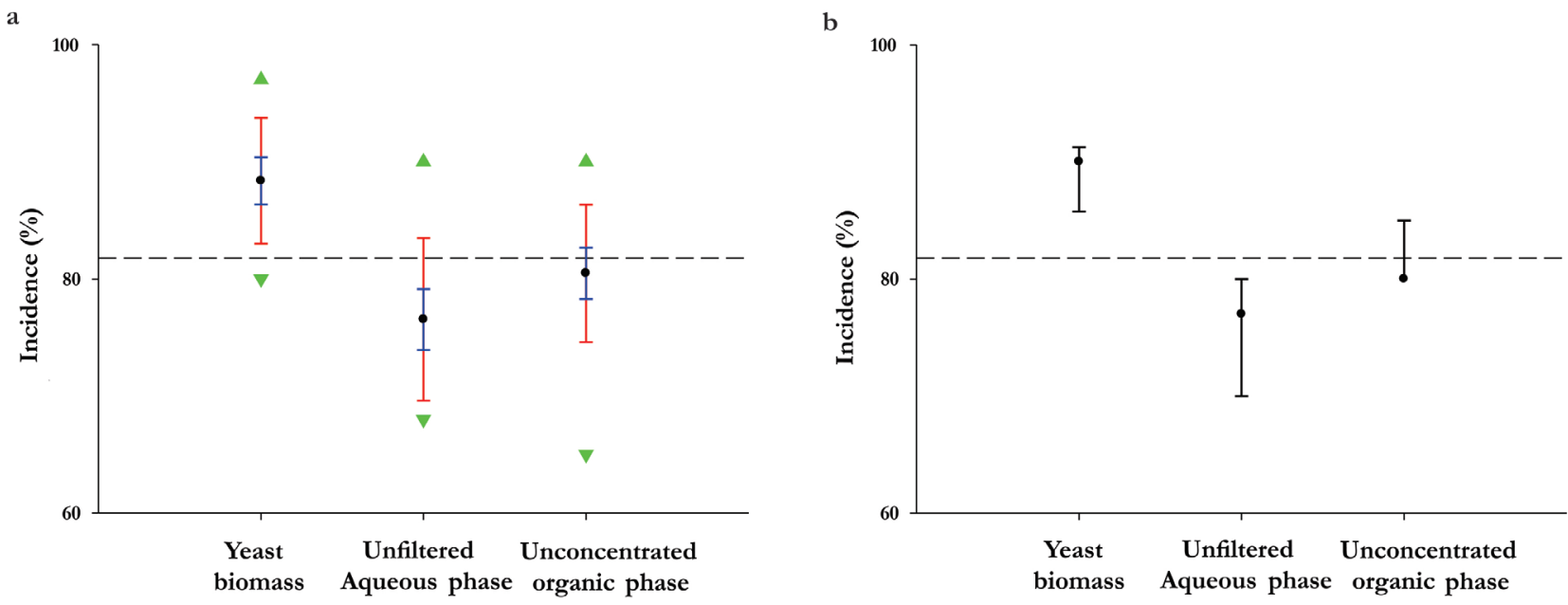
produced by the yeast, especially the higher alcohols, have a synergistic effect in the protection of the tomato; these metabolites are reported to be pest, and pathogen controllers and Candida guillermondii are alcohol and acetate resistant. Soluble sugars (carbon source) such as glucose and fructose in tomatoes and nitrogen sources (free amino acids) like aspartic acid and glutamic acid predominantly in mature tomatoes provide the yeast with nutrients, which they rapidly use to promote their adaptation and rapid growth throughout the fruit and wound area. The consumption of nutrients reduces the possibility of conidial germination and hyphal growth of Rhizopus stolonifer facilitating the biocontrol by nutrients competition

\section{Conclusion}

Based on our results, the biomass of Candida guillermondii and its metabolites, and especially higher alcohols, are the most promising postharvest Rbizopus stolonifer control treatments for tomatoes. Our data showed maximum antifungal efficacy in the in vivo assay using yeast biomass ( $88 \%$ of protection) and the organic phase containing metabolites ( $80 \%$ of protection). We believe yeast biomass and its metabolites have a synergistic role in the protection of tomatoes due to the rapid yeast biomass growth throughout the tomato wound area and the antifungal activity of its metabolites. This study presents a viable solution to minimize economic losses caused by pathogens, in addition to ensuring a longer tomato shelf life, which would guarantee a better product distribution. In doing so, we address a major problem and provide an advantageous solution to avoiding losses in this time of food crisis, especially in developing countries

\section{Acknowledgements}

The authors acknowledge the collaboration of Professor Ruben Torrenegra Guerrero, professor at the Universidad de Ciencias Aplicadas y Ambientales (UDCA), and his support. Thank you to the Vicerrectoría Academica at Pontificia Universidad Javeriana-Bogotá for funding this project; Ref: 120107F0401200.

\section{Conflicts of interest}

The authors agree with the results published in this article and state that there are no conflicts of interest.

\section{References}

Ando H, Hatanaka K, Ohata I, Yamashita-Kitaguchi Y, Kurata A, et al. (2012) Antifungal activities of volatile substances generated by yeast isolated from Iranian commercial cheese. Food Control 26:472-478 doi: 10.1016/j.foodcont.2012.02.017

Arras G, De Cicco V, Arru S, Lima G (1998) Biocontrol by yeasts of blue mold of citrus fruits and the mode of action of an isolate of Pichia guilliermondii. Journal of Horticulture Science Biotechnology 73:413-18

Atsumi S, Cann AF, Connor MR, Shen CR, Smith KM, et al. (2008) Metabolic engineering of Escherichia coli for 1-butanol production. Metabolic Engineering 10:305-311 doi: 10.1016/j.ymben.2007.08.003

Badawy ME, Rabea EI (2009) Potential of the biopolymer chitosan with different molecular weights to control postharvest gray mold of tomato fruit. Postharvest Biology and Technology 51:110-117 doi: 10.1016/j. postharvbio.2008.05.018

Bajpai VK, Shukla S, Kanga SC (2008) Chemical composition and antifungal activity of essential oil and various extract of Silene armeria. Bioresource Technology 99:8903-8908 doi: 10.1016/j.biortech.2008.04.060

Borrero C (2011) Caracterización molecular de una cepa de Candida sp. Trabajo de grado, Facultad de Ciencias, Pontificia Universidad Javeriana, Colombia

Cook RJ, Tjamos C, Papavizas GC (1992) Biological control of plant diseases. In: progress and challenges for the future. NATO ASI series, Scientific Affairs Division, New York, USA. pp.113-207

Cook DWM, Long PG, Ganesh S, Cheah LH (1997) Attachment microbes antagonistic against Botrytis cinerea-biological control and scanning electron microscope studies in vivo. Annals of Applied Biology 131:503-518

Cook DWM, Long PG, Ganesh S (1999) The combined effect of delayed application of yeast biocontrol agents and fruit curing for the inhibition of the postharvest pathogen Botrytis cinerea in kiwi fruit. Postharvest Biology and Technology 16:233-243 doi: 10.1016/S09255214(99)00003-4

Dik AJ, Koning G, Köhl J (1999) Evaluation of microbial antagonists for biological control of Botrytis cinerea stem infection in cucumber and tomato. European Journal of Plant Pathology 105:115-122 doi: 10.1023/A:1008623210258

Domínguez I, Ferreres F, Riquelme F, Fonta R, Gil M (2012) Influence of pre-harvest application of fungicides on the post-harvest quality of tomato (Solanum lycopersicum L.). Postharvest Biology and Technology 72:110 doi: 10.1016/j.postharvbio.2012.04.010 
Elad Y (2000) Biological control of foliar pathogens by means of Trichoderma harzianum and potential modes of action. Crops Protection 19:709-714 doi: 10.1016/ S0261-2194(00)00094-6

FAO-Departamento de agricultura (1997) http://www. fao.org/docrep/x5056s/x5056S07.htm Consulted October 32013

FAO-Departamento de Estadísticas (2012) http://www. fao.org/statistics/es/ Consulted October 32013

Food and Drug Administration-FDA (2013) CFR-Code of Federal Regulations Title 21 http:/ /www.accessdata. fda.gov/scripts/cdrh/cfdocs/cfcfr/CFRSearch. cfm?fr=173.160 Consulted November 202013

Heuvelink EP (2005) Tomatoes. CABI publishing, Cambridge, USA

Infante-Luna E, Marquinez-Casas X, Moreno G (2012) Tomato peel (Solanum lycopersicum L.) colonization by the endophyte yeast Candida guilliermondii (Castellani) Langeron et Guerra. Agronomia Colombiana 30:388394

Jones B, Jones J, Stall R, Zitter T (1991) Postharvest diseases and disorders of tomato fruit. In: Compendium of tomato diseases. Jones J. APS press, Minnesota, USA, pp 44-48

Morin L, Reid AM, Sims-Chilton NM, Buckley YM, Dhileepan K and et al. (2009) Review of approaches to evaluate the effectiveness of weed biological control agents. Biological Control 51(1):1-15 doi: 10.1016/j. biocontrol.2009.05.017

Nuez F (2001) Situación taxonómica, domesticación y difusión del tomate; anatomía y fisiología de la planta. En: El cultivo del tomate. Grafo S.A., Bilbao, España, pp 1-87

Onuegbu BA (2002) Fundamentals of Crop Protection, ASCEU, RSUST, Port Harcourt, Niger, pp 204-208

Palumbo M, Harris L (2011) Microbiological food safety of olive oil: A Review of the literature http://sfp.ucdavis. edu/files/146256.pdf Consulted November 192013

Peynaud E (1956) Sur la formation de l'acet!ate d'!ethyle par les levures du vin. Industries Agricoles Alimentaires 73:253-2577.

Plata C, Millan C, Mauricio JC, Ortega JM (2003) Formation of ethyl acetate and isoamyl acetate by various species of wine yeasts. Food Microbiology 20:217-224 doi: 10.1016/S0740-0020(02)00101-6

Roberts RG (1990) Postharvest biological control of gray of apple by Crytococcus laurentii. Phytopathology 80:526-530

Rojas V, Gil JV, Pinaga F, Manzanares P (2001) Studies on acetate ester production by non-Saccharomyces wine yeasts. International Journal of Food Microbiology 70:283289 doi: 10.1016/S0168-1605(01)00552-9
Singleton L, Minhail JD, Rush CM (1993) Methods for research on soilborne phytopathogenic fungi. APS Press, St. Paul, USA. 265 p.

Spadaro D, Gullino ML (2004) State of art and future prospects of biological control of postharvest fruit diseases. International Journal of Food Microbiology 91:185194 doi: 10.1016/S0168-1605(03)00380-5

Spadaro D, Gullino ML (2010) Opportunities and constraints in the development of antagonistic yeasts for the control of postharvest diseases of fruit. Stewart Postharvest Review 3:1-8 doi: 10.2212/spr.2010.3.7

Stevens C, Khan V, Lu J, Wilson C, Pusey P and et al. (1997) Integration of ultraviolet (UV-C) light with yeast treatment for control of postharvest storage rots of fruits and vegetables. Biological Control 10:98-103 doi: 10.1006/bcon.1997.0551

Wisniewski M, Biles C, Droby S, McLaughlin R, Wilson C, Chalutz E (1991) Mode of action of the postharvest biocontrol yeast, Pichia guilliermondii. I. Characterization of attachment to Botrytis cinerea. Physiological and Molecular Plant Pathology 39:245-258

Xi L, Tian SP (2005) Control of postharvest diseases of tomato fruit by combining antagonistic yeast with sodium bicarbonate. Scientia Agrciultura Sinica 38(5):950_ 955

Zabka M,Pavela R (2013) Antifungal efficacy of somenatural phenolic compounds against significant pathogenic and toxinogenic filamentous fungi. Chemosphere 93:10511056 doi: 10.1016/j.chemosphere.2013.05.076

Zhao Y, Tua K, Tub S, Liua M, Sua J, Houam Y (2010) A combination of heat treatment and Picbia guilliermondii prevents cherry tomato spoilage by fungi. International Journal of Food Microbiology 137:106-110 doi: 10.1016/j. ijfoodmicro.2009.11.002 


\section{Determinación de la efectividad del control biológico de Rhizopus stolonifer en tomates poscosecha utilizando candida guilliermondii}

Resumen. Las alteraciones de frutos de tomate poscosecha por causas microbiológicas conllevan a su deterioro fisiológico produciendo su descomposición. En este estudio, Candida guilliermondii fue examinada en ensayos in vitro e in vivo para determinar su eficacia en el control biológico contra Rhizopus stolonifer en tomates (Lycopersicon esculentum). El efecto antagónico se llevo a cabo usando biomasa de la levadura y sus metabolitos los cuales se identificados en un cromatógrafo gases-masas. Los ensayos in vitro mostraron que la única fase con respuesta antagónica al patógeno fue la fase acuosa sin filtrar. En los ensayos in vivo, la biomasa de Candida guilliermondii presento el mayor porcentaje de protección contra el patógeno $(87$ \%) en comparación con la fase acuosa sin filtrar y la fase orgánica sin concentrar que presentaron el 77 y $80 \%$ de protección respectivamente. Estos resultados son de gran importancia para evitar las perdidas económicas además de garantizar un tiempo de vida mas largo del tomate asegurando una mejor distribución del producto y evitando sus perdidas en estos tiempos de crisis alimentaria en especial en países en desarrollo.

Palabras clave: Control biológico; Candida guilliermondii; Rhizopus stolonifer, tomates (Lycopersicon esculentum).
Determinaçáo da efetividade do controlo biológico de Rhizopus stolonifer em tomates poscosecha utilizando candida guilliermondii

Resumo. As perdas pós-colheita de frutos de tomate são creditadas em várias fontes, incluindo causas biológicas que levam ao deterioro fisiológico e infecção por doenças e pragas que podem levar à sua decomposição. Neste estudo, a levedura Candida guilliermondii foi examinada in vitro in vivo para determinar a sua eficácia no controlo biológico de Rhizopus stolonifer em tomates (Lycopersicon esculentum). O efeito antagonista realizouse utilizando biomassa de levedura e os seus metabolitos, os quais foram identificados por cromatografia gasosa acoplada a um detector selectivo de massa. Os ensaios in vitro mostraram que a única fase com resposta antagonista a Rhizopus stolonifer foi a fase aquosa não filtrada. Nos ensaios in vivo, a biomassa Candida guilliermondii teve a maior percentagem de protecção contra o patógeno (87\%) em comparação com a fase aquosa não filtrada e a fase orgânica não concentrada apresentando 77 e 80 \% de protecção, respectivamente. Estes resultados são muito importantes para evitar perdas económicas causadas por fungos, além de garantir ao tomate uma vida útil mais longa, o que assegura uma melhor distribuição do produto e evita perdas pós-colheita neste momento de crise alimentar, especialmente nos países em desenvolvimento.

Palavras-chave: Controlo biológico; Candida guilliermondii; Rhizopus stolonifer, tomates (Lycopersicon esculentum). 